\title{
Anchoring of Azospirillum brasilense to hydrophobic polystyrene and wheat roots
}

\author{
YOAv BASHaN* and Gina Holguin \\ Department of Microbiology, Division of Experimental Biology, The Center for Biological Research, (CIB), \\ La Paz, PO Box 128, BCS, Mexico 23000
}

(Received 20 February 1992; revised 19 October 1992; accepted 20 October 1992)

\begin{abstract}
The anchoring (irreversible attachment) of Azospirillium brasilense $\mathrm{Cd}$ to hydrophobic polystyrene and to root surfaces was compared. Live $A$. brasilense $C d$ cells attached in significantly greater numbers to roots than to polystyrene, regardless of treatments made to the surfaces or to the bacterial cells. Triton $\mathrm{X}-100, \mathrm{Na}_{2} \mathrm{EDTA}$ and several bacterial-inhibitory substances reduced bacterial attachment to both surfaces, although this effect was greater with attachment to polystyrene than to roots. Pre-coating with root exudates, bovine serum albumin or gelatin significantly increased anchoring to both surfaces. Manganese-limited cells showed increased anchoring to roots, whereas dead cells adsorbed better to polystyrene. Although the anchoring of $A$. brasilense $\mathrm{Cd}$ to a nonbiological surface can be significantly altered by using several promoting or inhibiting substances to affect the properties of both the surface and the bacterial cell, anchoring to root surfaces is less affected by these substances. It is proposed that at least two different quantitative types of anchoring exist in this bacterium: a sparse attachment to a non-biological surface and a prolific attachment to roots.
\end{abstract}

\section{Introduction}

Efficient root colonization is a major factor when assessing the effect of beneficial plant-associated bacteria (Bashan \& Levanony, 1990). Azospirillum species are able to colonize root surfaces of a wide variety of plant species (Bashan et al., 1989), the interior cortex of cereal roots (Levanony et al., 1989), isolated cells (Eyers et al., 1988), or synthetic inoculants (Bashan, 1986b). They are distributed along the root system (Baldani et al., 1986), but are concentrated mainly in the elongation and roothair zones (Bashan et al., 1991).

Azospirillum is able to colonize roots permanently and irreversibly for extended periods (Bashan et al., 1987; Harris et al. 1989). Colonization occurs mainly on the root surfaces (and to a lesser extent on root hairs) by means of extensive formation of fibrillar material which connects the bacterial cells to the roots irreversibly (Levanony \& Bashan, 1991). The fibrils which form have been defined as being proteinaceous or polysaccharide in nature (Bashan \& Levanony, 1988b; Michiels et al.,

*Author for correspondence. Fax 005268253625.

Abbreviations: ANOVA, analysis of variance; TTC, triphenyltetrazolium chloride.
1991). However, the mechanism of attachment is, as yet, not completely resolved. It has been speculated that these fibrils contain receptors to plant agglutinins and lectins (Bashan \& Levanony, 1988c: Del Gallo et al., 1989; Madi \& Henis, 1989). Lectins have been implicated in Rhizobium recognition and attachment to plant host cells (Smit \& Stacey, 1990). To date, attachment of Azospirillum to roots has not been compared with attachment to other hydrophobic surfaces which are commonly used to evaluate the attachment of bacteria responsible for biofouling in other environments (Fletcher, 1977; Klotz, 1990).

Michiels et al. (1991) proposed two different modes of attachment of Azospirillum brasilense to wheat roots, similar to those previously proposed by Marshall (1986) for the attachment of soil bacteria to soil particles. The primary absorption phase is fast, weak and governed by proteinaceous compounds as described previously by Bashan \& Levanony (1988b). The second phase (called anchoring) is stronger, irreversible and probably based on surface polysaccharides (Michiels et al., 1990). The anchoring phase, characterized by the production of long fibrils, has been observed in roots of several crop plants (Bashan et al., 1991) and is probably the major factor in effective root colonization which ultimately enhances plant growth (Bashan, 1986a; Bashan et al., 1989). 
The aims of this study were: (i) to investigate the anchoring phase of $A$. brasilense, and (ii) to establish its preference for living, heterogeneous surfaces such as roots. Comparisons were made of anchoring to roots and to a uniform polystyrene surface under diverse environments and surface treatments.

\section{Methods}

Organisms and bacterial growth conditions. The rhizosphere bacterium Azospirillium brasilenase Cd (ATCC 29710) and wheat seedlings (Triticum aestivum cv. Tikal; winter wheat) were used. Bacteria were grown and prepared for inoculation as described previously (Bashan \& Levanony, 1985). The cultures were grown for $16 \mathrm{~h}$ at $30 \pm 1^{\circ} \mathrm{C}$ in OAB $\mathrm{N}$-free medium of the following composition. Solution $\mathrm{A}$ : $\left(\mathrm{g}^{-1}\right)$ DL-malic acid, $5 ; \mathrm{NaOH}, 3 ; \mathrm{MgSO}_{4} .7 \mathrm{H}_{2} \mathrm{O}, 0.2 ; \mathrm{CaCl}_{2}, 0.02 ; \mathrm{NaCl}, 0.1$; $\mathrm{NH}_{4} \mathrm{Cl}, 1$; yeast extract, $0.1 ; \mathrm{FeCl}_{3}, 0.01 ;\left(\mathrm{mg} \mathrm{l}^{-1}\right) \mathrm{NaMoO}_{4} .2 \mathrm{H}_{2} \mathrm{O}, 2$; $\mathrm{MnSO}_{4}, 2 \cdot 1 ; \mathrm{H}_{3} \mathrm{BO}_{3}, 2 \cdot 8 ; \mathrm{Cu}\left(\mathrm{NO}_{3}\right)_{2} .3 \mathrm{H}_{2} \mathrm{O}, 0 \cdot 04 ; \mathrm{ZnSO}_{4} .7 \mathrm{H}_{2} \mathrm{O}, 0 \cdot 24 ;$ $900 \mathrm{ml}$ distilled water. Solution $\mathrm{B}:\left(\mathrm{g} \mathrm{l}^{-1}\right) \mathrm{K}_{2} \mathrm{HPO}_{4}, 6 ; \mathrm{KH}_{2} \mathrm{PO}_{4}, 4$; $100 \mathrm{ml}$ distilled water. After separate autoclaving and cooling, the two solutions were mixed and the $\mathrm{pH}$ was adjusted to 6.8 with $\mathrm{NaOH}$ (Okon et al., 1977). To avoid self-aggregation, the bacteria were grown in Erlenmeyer flasks with shallow grooves, shaken at 250 r.p.m. for $16 \mathrm{~h}$. This allowed the harvesting of non-aggregated bacteria in the exponential phase of growth. Carbon- or manganese-limited cells were obtained by transferring double-washed cells grown in OAB medium into an identical medium with either $0.1 \%$ of the original carbon source $\left(0.5 \mathrm{~g} \mathrm{DL}^{-m a l i c ~ a c i d ~} \mathrm{l}^{-1}\right)$ or $0.1 \%$ of the original $\mathrm{MnSO}_{4}\left(0.2 \mathrm{mg} \mathrm{l}^{-1}\right)$ for $24 \mathrm{~h}$ at $30 \pm 1^{\circ} \mathrm{C}$. Aggregates formed in the latter two media were removed by filtration through sterile filter paper (Whatman no. 42).

Anchoring assays. (i) To hydrophobic polystyrene. Cells of A. brasilense $\mathrm{Cd}$ from exponential-phase cultures were centrifuged at $7000 \mathrm{~g}$ for $10 \mathrm{~min}$, washed twiced in deionized water, and resuspended in $0.05 \mathrm{M}$-potassium phosphate buffer $\mathrm{pH} \mathrm{6.1}$ supplemented with

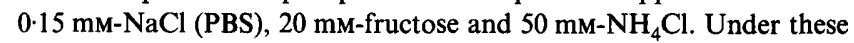
conditions, the bacteria are able to multiply and produce abundant amounts of fibrillar material. The suspension was adjusted to $1 \times 10^{7}$ c.f.u. $\mathrm{ml}^{-1}\left(1.05 A_{540}\right.$ units $=10^{9}$ c.f.u. $\left.\mathrm{ml}^{-1}\right)$. Twenty millilitres of bacterial suspension was poured into each of a series of hydrophobic polystyrene Petri dishes, $9 \mathrm{~cm}$ in diameter (Fisher). The suspension was decanted after $48 \mathrm{~h}$ static incubation at $30 \pm 2^{\circ} \mathrm{C}$. In one case, incubation periods of $24 \mathrm{~h}$ and $72 \mathrm{~h}$ were also tested. The dishes were very gently rinsed once with $50 \mathrm{ml}$ sterile distilled water and the adsorbed bacteria were fixed to the polystyrene with $5 \%(\mathrm{v} / \mathrm{v})$ glutaraldehyde for $2 \mathrm{~h}$ at ambient temperature. Scanning electron micrographs verified the anchoring of the bacteria via fibrils. A vortex treatment to distinguish between the adsorbed bacteria and the anchored bacteria was not performed since it had been determined that such a treatment could break the fibrils, resulting in lower values of anchoring (Bashan et al., 1986). A freshly prepared, filtered solution of crystal violet was added to cover the bottom of each dish. After 5 min, the stain was decanted and the dishes were rinsed repeatedly and slowly with running sterile distilled water to remove excess stain, then dried with a hair dryer. The adsorbed bacteria were counted by a modification of the spectroscopic method of Fletcher (1976). The entire surface of each dish $\left(6350 \mathrm{~mm}^{2}\right)$ was scanned by a scanning spectrophotometer at $590 \mathrm{~nm}$ (the wavelength of maximum absorbance for crystal violet). The absorbance value was correlated to bacterial numbers by taking scanning electron micrographs of the measured areas and counting the bacteria in the photographs. Seventy-two such counts were made. A linear correlation between the number of bacteria and absorbance was found $(r=0.984)$, with a lower limit of approximately 500 c.f.u. per sample. Lower attachment levels could not be accurately measured by this method, being indistinguishable from the background. However, since the scanned area of the Petri dishes was 100 times larger than the compared root surfaces, it was possible to compare and calculate the number of bacteria adsorbed to similar-sized areas when 100 times less inoculum was required to inoculate the roots (see below). Stained, buffer-treated, uninoculated Petri dishes or unstained, inoculated dishes were used as controls.

(ii) To roots. Assays were done on excised roots from plants grown in aeroponic growth conditions as previously described in detail (Bashan \& Levanony, 1989). Bacteria were prepared for inoculation as described above. Except for the bacterial density (for the reasons explained above), assay conditions for both surfaces were identical.

From the root-hair zone, root segments $1 \mathrm{~mm}$ in diameter and $19 \mathrm{~mm}$ in length were obtained, giving an average surface area of $60 \pm 1.2 \mathrm{~mm}^{2}$ per sample (mean of 211 determinations), using $10^{5}$ c.f.u. $\mathrm{ml}^{-1}$. Higher inoculation levels $\left(10^{6}-10^{7}\right.$ c.f.u. $\left.\mathrm{ml}^{-1}\right)$ produced aggregated colonization on roots (Levanony et al., 1989), which causes a higher variation in the bacterial counts. A high inoculation level of $10^{8}$ c.f.u. $\mathrm{ml}^{-1}$ (or an equivalent number of dead cells), was used only once in experiments designed to count bacteria by the ELISA technique, which has a detection threshold of $10^{4}$ c.f.u. $\mathrm{ml}^{-1}$ or more, without differentiating between live or dead cells (Levanony et al., 1987). Colonization was measured on the root-surface of the root hair zone.

Pre-coating of roots, bacteria and polystyrene. Prior to inoculation, roots and polystyrene surfaces were coated by dipping (roots) or filling (Petri dishes) with PBS solution supplemented with the following substances: Triton X-100 (Rohm and Hass) at $10 \mu 1 \mathrm{l}^{-1}$, streptomycin sulphate (Sigma) at $200 \mathrm{mg} \mathrm{l}^{-1}, 2,3,5$-triphenyltetrazolium chloride (TTC) (Riedel de Haen) at $15 \mathrm{mg} \mathrm{l}^{-1}$, neomycin sulphate (Sigma) at $200 \mathrm{mg} \mathrm{l}^{-1}, \mathrm{KCN}$ at 5 or $100 \mathrm{mg} \mathrm{l}^{-1}$; methyl violet at $60 \mathrm{mgl}^{-1}$, tetracycline (Sigma) at $200 \mathrm{mg} \mathrm{l}^{-1}$, chloramphenicol (Sigma) at $250 \mathrm{mg}$ $\mathrm{I}^{-1}$, root exudates at $100 \mathrm{mg} \mathrm{m}^{-1}$ (Gafni et al. 1986), or $1 \mathrm{~mm}$ $\mathrm{Na}_{2}$ EDTA. The following proteins were used at $0 \cdot 2 \%$ : bovine serum albumin (BDH), gelatin (type A, Sigma), fibrinogen (from bovine plasma, type 1-S, Sigma), pepsin (Sigma) and histone (type III-S, Sigma). Pepsin had no enzymic activity under the conditions described above, as it is only active at acidic pH (Fletcher, 1976). Histone was dissolved in acidified distilled water (Fletcher, 1976). All materials except histone and $\mathrm{KCN}$ left the dish surface completely wettable, indicating the formation of an adsorbed film. After $2 \mathrm{~h}$ incubation at ambient temperature, the solutions were pumped out by a small vacuum pump equipped with a Pasteur pipette. A. brasilense $\mathrm{Cd}$ suspensions were immediately added to the wet surfaces. Additional controls were dishes treated with each of the materials and stained, but not inoculated.

In additional experiments, the bacterial culture was treated with the final concentrations of substances listed above $3 \mathrm{~h}$ before extraction of bacteria from the culture for the attachment assays.

Dead bacteria. Bacteria were killed either by heat treatment $(30 \mathrm{~min}$, $100{ }^{\circ} \mathrm{C}$ ) or by fixation with $5 \%$ glutaraldehyde $(\mathrm{v} / \mathrm{v})$, final concentration) for $2 \mathrm{~h}$ at $25 \pm 2{ }^{\circ} \mathrm{C}$. The dead bacteria were rinsed twice with PBS before they were used in the attachment assay. Dead bacteria were counted by the indirect-ELISA technique (Levanony et al., 1987).

Experimental design and statistical analysis. All experiments were done with five replicates per treatment. A replicate consisted of three root segments or one Petri dish. Numerous scanning spectroscopic determinations were performed on every dish, eventually covering the entire surface of the dish. All experiments were repeated twice, and data from both experiments were used for statistical analysis. Results were 
taken as significantly different if $P \leqslant 0.05$ in a one-way analysis of variance (ANOVA).

\section{Results}

\section{Anchoring of $A$. brasilense $C d$ to polystyrene and to wheat roots after different incubation times}

The anchoring of $A$. brasilense $\mathrm{Cd}$ to roots was greater than that to polystyrene (Fig. 1). Anchoring to roots rapidly increased to its maximum after incubation for $48 \mathrm{~h}$ and remained constant thereafter. Anchoring to polystyrene also increased with time, but more slowly. The ratio of bacterial attachment between root and polystyrene thus decreased from $1 \cdot 9: 1$ to $1 \cdot 2: 1$ between $24 \mathrm{~h}$ and $72 \mathrm{~h}$ (Fig. 1).

\section{Effects of a surfactant, antibiotics and bacterial- inhibitory substances on anchoring to roots and polystyrene}

Application of the bacterial-inhibitory substances (with the exception of streptomycin sulphate) and Triton X100 , either to the bacterial culture or to polystyrene and root surfaces, reduced the anchoring of bacteria to both surfaces (Fig. 2a,b). Treatment of the bacterial culture with Triton X-100, TTC, methyl violet, tetracycline, chloramphenicol or a high concentration of $\mathrm{KCN}$ prior to the attachment assay almost eliminated anchoring to the surfaces. Anchoring of treated bacteria to both roots and polystyrene was less inhibited by neomycin sulphate and a lower concentration of $\mathrm{KCN}$ (Fig. $2 a$ ).

When the same inhibitory substances were spread on polystyrene and root surfaces prior to bacterial inoculation, a different response was observed. The substances reduced anchoring to polystyrene significantly more than anchoring to roots (Fig. $2 b$ ). Untreated bacteria attached better to treated root surfaces than treated bacteria attached to untreated surfaces.

\section{Effects on anchoring of pre-coating the surfaces with proteins, root exudates, or $N a_{2} E D T A$}

When roots or polystyrene surfaces were coated with various proteins, inoculated with $A$. brasilense $\mathrm{Cd}$, and then incubated, two of the proteins, bovine serum albumin and gelatin, significantly increased bacterial anchoring to both surfaces. Anchoring levels for all treatments, regardless of their effectiveness, were greater to roots than to polystyrene (Fig. $3 a, b$ ). The treatment of both surfaces with root exudates significantly increased anchoring, whereas the $\mathrm{Na}_{2}$ EDTA treatment almost

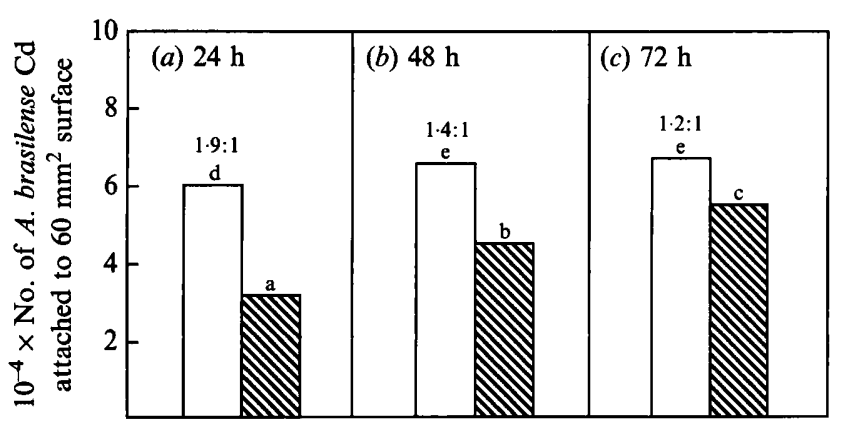

Fig. 1. Anchoring of A. brasilense Cd to root $(\square)$ and polystyrene ( $(\mathbb{)})$ surfaces after different incubation periods. Columns with a different lower-case letter differ significantly at $P \leqslant 0.05$ in a one-way ANOVA. The ratio of bacterial anchoring (in cells) between roots and polystyrene surfaces is shown for each panel.
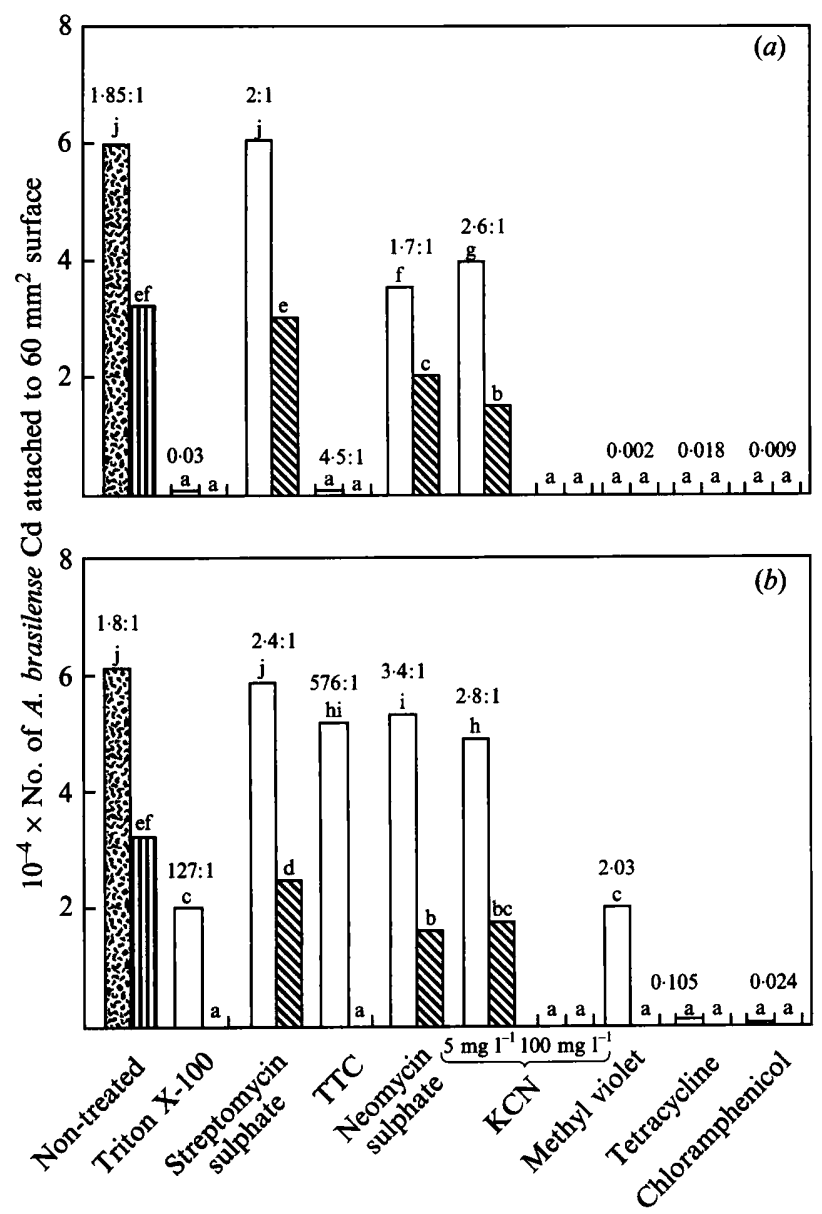

Fig. 2. Anchoring of $A$. brasilense $\mathrm{Cd}$ to root and polystyrene surfaces after the bacteria $(a)$ or the surface $(b)$ were treated with various agents prior to the anchoring assays. Columns with a different lower-case letter (panels $a$ and $b$ considered separately) differ significantly from each other at $P \leqslant 0.05$ in a one-way ANOVA. Ratios of bacterial anchoring (in cells) between roots and polystyrene surfaces are shown for each treatment. Numbers above minimal values represent the actual number of bacteria anchored to the surface in that treatment. 圈,

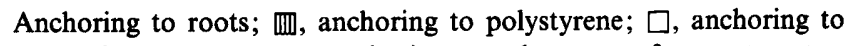
roots after treatment; $\mathbb{\mathbb { N }}$, anchoring to polystyrene after treatment. 


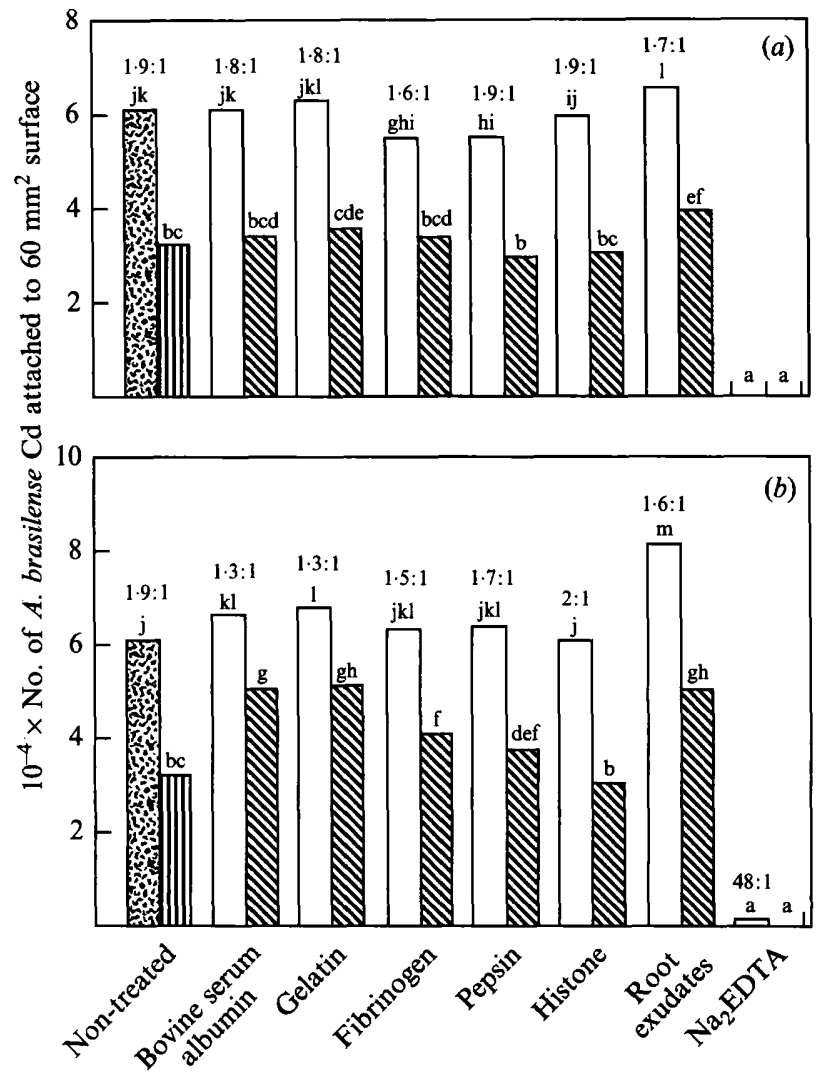

Fig. 3. Anchoring of $A$. brasilense $\mathrm{Cd}$ to root and polystyrene surfaces after the bacteria $(a)$ or the surfaces $(b)$ were treated with various proteins, root exudates or $\mathrm{Na}_{2}$ EDTA prior to the anchoring assays. Columns with a different lower-case letter (panels $a$ and $b$ considered separately) differ significantly from each other at $P \leqslant 0.05$ in a one-way ANOVA. Ratios of bacterial anchoring (in cells) between roots and polystyrene surfaces are shown for each treatment. 圆, Anchoring to roots; $[\mathrm{l}$, anchoring to polystyrene; $\square$, anchoring to roots after

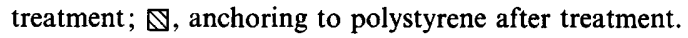

eliminated anchoring (Fig. $3 b$ ). When the proteins were added to bacterial cultures prior to inoculation, they had no significant effect on the resulting anchoring. $\mathrm{Na}_{2}$ EDTA
Table 2. Attachment of dead A. brasilense Cd to polystyrene surfaces precoated with various proteins

The bacteria were killed by heat. The number of bacteria in the inoculum before killing was $3.8 \times 10^{7} \mathrm{ml}^{-1}$.

\begin{tabular}{lc}
\hline \multicolumn{1}{c}{$\begin{array}{c}\text { Surface } \\
\text { treatment }\end{array}$} & $\begin{array}{c}10^{-6} \times \text { No. of bacteria } \\
\text { attached to } \\
60 \mathrm{~mm}^{2} \text { surface }( \pm \mathrm{SE})\end{array}$ \\
\hline Not treated & $3 \cdot 3 \pm 0 \cdot 9$ \\
Bovine serum albumin & $4 \cdot 1 \pm 1 \cdot 3$ \\
Gelatin & $3 \cdot 7 \pm 1 \cdot 4$ \\
Fibrinogen & $2 \cdot 4 \pm 1 \cdot 7$ \\
Pepsin & $2 \cdot 9 \pm 1 \cdot 6$ \\
\hline \hline
\end{tabular}

retained its negative effect and root exudates retained their positive effect (Fig. $3 a$ ).

\section{Attachment of dead A. brasilense Cd cells to roots and polystyrene}

Killing the bacteria prior to application to the roots almost abolished attachment: only $0 \cdot 1-0 \cdot 13 \%$ of the original population attached. Killing the bacteria had a lesser effect on attachment to polystyrene: $5-12.8 \%$ of the original population attached to the surface (Table 1). Coating the polystyrene with various proteins prior to applying the dead bacteria had no effect on the amount of attachment, regardless of the treatment (Table 2).

\section{Effect of manganese and carbon limitations on anchoring}

Manganese-limited cells anchored better to roots than did non-limited cells, but they anchored less well than non-limited cells to polystyrene (Fig. 4). Carbon-limited cells anchored less well than non-limited cells to both

Table 1. Attachment of dead A. brasilense Cd to roots and to polystyrene

Numbers of dead bacteria on roots were estimated by indirect ELISA (Levanony et al., 1987).

\begin{tabular}{|c|c|c|c|c|}
\hline \multirow[b]{3}{*}{$\begin{array}{c}\text { Bacterial } \\
\text { treatment }\end{array}$} & \multicolumn{4}{|c|}{ Bacteria attached to $60 \mathrm{~mm}^{2}$ surface } \\
\hline & \multicolumn{2}{|c|}{ Roots } & \multicolumn{2}{|c|}{ Polystyrene } \\
\hline & $\begin{array}{c}\text { No. of } \\
\text { bacteria } \\
( \pm \mathrm{SE})\end{array}$ & $\begin{array}{l}\text { Percentage } \\
\text { of live } \\
\text { control }\end{array}$ & $\begin{array}{c}\text { No. of } \\
\text { bacteria } \\
( \pm \mathrm{SE})\end{array}$ & $\begin{array}{c}\text { Percentage } \\
\text { of live } \\
\text { control }\end{array}$ \\
\hline Live bacteria & $(6 \cdot 2 \pm 0.4) \times 10^{7}$ & 100 & $(3 \cdot 2 \pm 0.6) \times 10^{7}$ & 100 \\
\hline Heat-killed bacteria* & $(8.4 \pm 1.7) \times 10^{4}$ & $0 \cdot 13$ & $(4.1 \pm 0 \cdot 8) \times 10^{6}$ & $12 \cdot 8$ \\
\hline $\begin{array}{l}\text { Glutaraldehyde- } \\
\text { killed bacteria* }\end{array}$ & $(6 \cdot 3 \pm 1 \cdot 1) \times 10^{4}$ & $0 \cdot 1$ & $(1.6 \pm 0.4) \times 10^{6}$ & 5 \\
\hline
\end{tabular}

${ }^{*}$ Bacteria were killed either by heat treatment $\left(30 \mathrm{~min}, 100^{\circ} \mathrm{C}\right)$ or by fixation with $5 \%(\mathrm{v} / \mathrm{v})$ glutaraldehyde for $2 \mathrm{~h}$ at $25 \pm 2^{\circ} \mathrm{C}$. 


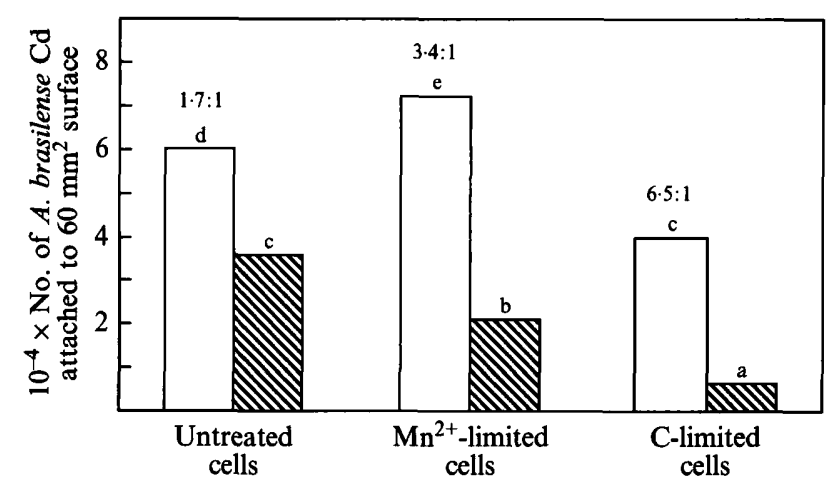

Fig. 4. Anchoring of manganese-limited cells and carbon-limited cells of $A$. brasilense Cd to root $(\square)$ and polystyrene $(\mathbb{\$})$ surfaces. Columns with a different lower-case letter differ significantly at $P \leqslant 0.05$ in a oneWay ANOVA. Ratios of bacterial anchoring (in cells) between roots and polystyrene surfaces are shown for each type of cell.

roots and polystyrene; however, the ratio was higher than for normal cells (Fig. 4).

\section{Discussion}

Bacterial attachment appears to have two distinct phases: (i) reversible adhesion based mainly on physicochemical bonds (ionic, hydrophobic) which are usually weak, non-specific and allow the cells to be easily detached from roots, and (ii) irreversible attachment, or anchoring, in which the bacteria-surface interaction forms a network of substances which permanently binds the bacteria to the surface (Marshall, 1986). Although the attachment of $A$. brasilense to roots has these two phases (Michiels et al., 1991), long-term colonization and rhizocompetence is based mainly on the anchoring phase of the attachment process (James et al., 1985).

The secure attachment of beneficial bacteria is essential for a long-term association with the host plant for three reasons. (i) If the bacteria are not attached to root epidermal cells, substances extracted by the bacteria diffuse into the rhizosphere, where they are consumed by nutritionally-versatile micro-organisms before reaching the target plant. However, when the bacteria attach to the roots, part of these substances are diffused from their longitudinal side into the intercellular spaces of the root cortex. This is especially true for bacterial aggregate colonization where attachment is horizontal to the root surface (Levanony et al., 1989). (ii) Without a secure attachment, water may wash the bacteria away from the rhizosphere to perish in the surrounding, nutrientdeficient soil. Azospirillum is known to survive poorly in soils without plants to act as hosts (Bashan \& Levanony, 1990). (iii) Association sites on roots with no attached beneficial bacteria are vulnerable to other aggressive, non-beneficial colonizers.
Bacterial attachment can be specific, as in Rhizobium-legume interactions (Smit \& Stacey, 1990) or nonspecific as in the case of Azospirillum, which is capable of attachment to nearly every root system tested so far (Bashan \& Levanony, 1990). The present study focused on the anchoring phase of $A$. brasilense attachment both to roots and to polystyrene surfaces; both these surfaces are primarily hydrophobic in nature. These two surfaces were compared to evaluate the significance of both the bacteria and the surface on the anchoring phase. The differences in the anchoring ratios between the root and polystyrene surfaces reflect the effect of surface properties on the anchoring process.

The attachment of bacteria to surfaces is affected by various physicochemical factors of the cell and the surface (Fletcher \& Loeb, 1979), and by culture variables of concentration and age (Fletcher, 1977). Surface-active agents, antibiotic treatments or surface protein coatings reduce hydrophobic interactions, and in so doing reduce microbial adhesion to plastics (Fletcher, 1976; Klotz, 1990). Although these factors were considered important in the reversible adhesion phase (Fletcher \& Loeb, 1979), the present study demonstrates that they affect the anchoring phase as well. As expected, most substances applied to polystyrene surfaces inhibited the anchoring of $A$. brasilense Cd. However, when these substances were applied to roots, their inhibitory effect was smaller, probably because the metabolic activity of the roots inactivated a proportion of the substances.

A surprising result was the effect of two proteins, bovine serum albumin and gelatin, both of which are known to inhibit the primary bacterial adhesion of marine bacteria (Fletcher, 1976). In this study, the application of these proteins increased anchoring of $A$. brasilense $\mathrm{Cd}$ to both surfaces. Fibrinogen and pepsin also increased anchoring, but only to polystyrene. The reason for this phenomenon is still unclear. It is possible that the proteins served as a nutrient source for the applied bacteria, creating a larger bacterial population which attached to the surfaces only after most of the proteins were consumed. This hypothesis is indirectly supported by the fact that pre-coating polystyrene with these proteins did not increase the attachment of dead bacteria.

It has been shown that for Azospirillum to colonize roots, bacterial metabolism is far more important than the surface properties of the roots; live bacteria attached well to dead roots, but dead bacteria attached less to live roots (Bashan et al., 1986). In this study, dead bacteria attached better to polystyrene than to roots, providing further support for the hypothesis that the primary adhesion mechanism of $A$. brasilense is physicochemical in nature, rather than biological as was suggested for many bacterial species (Cope, 1980). 
Rhizobium is known to produce fimbriae which participate in the attachment to the plant. This attachment is greatly affected by the nutritional status of the bacterial cells prior to inoculation, and especially by carbon and manganese limitations (Kijne et al., 1988; Smit \& Stacey, 1990). Our study provides preliminary evidence that, as observed for Rhizobium leguminosarum, manganese-limited cells of $A$. brasilense $\mathrm{Cd}$ anchor better to roots than do normal cells. Unlike rhizobia, the anchoring of carbon-limited cells of $A$. brasilense Cd to roots and polystyrene was less than for non-treated bacteria.

The preference of $A$. brasilense, a terrestrial bacterium, for living surfaces is surprising in view of the fact that medical and marine biofouling is pervasive on non-living surfaces. The skin of many marine mammals resists bacterial attachment throughout their life in a bacteriarich environment. The attachment of bacteria within the human body to plastic medical implants in preference to living tissues (Klotz, 1990) is the opposite phenomenon of that described in this study.

In conclusion, the anchoring of $A$. brasilense $\mathrm{Cd}$ to a non-biological surface can be significantly altered by using several promoting or inhibiting substances to affect the surface properties and the bacterial cell. Nevertheless, anchoring to the root surface is less affected by these substances. We propose that at least two different quantitative types of anchoring exist for this bacterium: a sparse attachment to a non-biological surface and a prolific attachment to roots.

This study was written in memory of the late Mr Avner Bashan from Israel and partially supported by Consejo Nacional de Ciencia y Tecnologia (CONACyT), Mexico, contract no. 0174-N9107. We thank Mr Roy Bowers for very careful English corrections and editing, and Mr Oscar Armendariz Ruiz for meticulous artwork.

\section{References}

Baldani, V. L. D., Alvarez, M. A. De B., Baldani, J. I. \& DöbeREINER, J. (1986). Establishment of inoculated Azospirillum spp. in the rhizosphere and in roots of field grown wheat and sorghum. Plant and Soil 90, 35-46.

BASHAN, Y. (1986a). Enhancement of wheat roots colonization and plant development by Azosprillium brasilense Cd following temporary depression of the rhizosphere microflora. Applied and Environmental Microbiology 51, 1067-1071.

BASHAN, Y. (1986b). Alginate beads as synthetic inoculant carriers for the slow release of bacteria that affect plant growth. Applied and Environmental Microbiology 51, 1089-1098.

Bashan, Y. \& LeVanony, H. (1985). An improved selection technique and medium for the isolation and enumeration of Azospirillum brasilense. Canadian Journal of Microbiology 31, 947-952.

Bashan, Y. \& LEVANONY, H. (1988a). Adsorption of the rhizosphere bacterium Azospirillum brasilense $\mathrm{Cd}$ to soil, sand and peat particles. Journal of General Microbiology 134, 1811-1820.

Bashan, Y. \& LeVANONY, H. (1988b). Active attachment of Azospirillum brasilense $\mathrm{Cd}$ to quartz sand and to light-textured soil by protein bridging. Joural of General Microbiology 134, 2269-2279.

Bashan, Y. \& LeVANONY, H. (1988c). Migration, colonization and adsorption of Azospirillum brasilense to wheat roots. In Lectins Biology, Biochemistry, Clinical Biochemistry, vol. 6, pp. 69-84. Edited by T. C. Bøg-Hansen \& D. L. J. Freed. St Louis, MO: Sigma Chemical Co.

Bashan, Y. \& LeVANONY, H. (1989). Factors affecting adsorption of Azospirillum brasilense $\mathrm{Cd}$ to root hairs as compared with root surface of wheat. Canadian Journal of Microbiology 35, 936-944.

Bashan, Y. \& LeVanony, H. (1990). Current status of Azospirillum inoculation technology: Azospirillum as a challenge to agriculture. Canadian Journal of Microbiology 36, 591-608.

Bashan, Y., LeVanony, H. \& Klein, E. (1986). Evidence for a weak active external adsorption of Azospirillum brasilense Cd to wheat roots. Journal of General Microbiology 132, 3069-3073.

Bashan, Y., LeVANONY, H. \& Whitmoyer, R. E. (1991). Root surface colonization of non-cereal crop plants by pleomorphic Azospirillum brasilense Cd. Journal of General Microbiology 137, 187-196.

Bashan, Y., LeVanony, H. \& Ziv-Vecht, O. (1987). The fate of fieldinoculated Azospirillum brasilense $\mathrm{Cd}$ in wheat rhizosphere during the growing season. Canadian Journal of Microbiology 33, 1074-1079.

Bashan, Y., Ream, Y., Levanony, H. \& Sade, A. (1989). Nonspecific responses in plant growth, yield, and root colonization of noncereal crop plants to inoculation with Azospirillum brasilense $\mathrm{Cd}$. Canadian Journal of Botany 67, 1317-1324.

COPE, W. A. (1980). Microbial surface components involved in adsorption of microorganisms to surfaces. In Adsorption of Microorganisms to Surfaces, pp. 105-144. Edited by G. Bitton \& K. C. Marshall. New York: Wiley Interscience.

Del Gallo, M., Negi, M. \& Neyra, C. A. (1989). Calcofluor- and lectin-binding exocellular polysaccharides of Azospirillum brasilense and Azospirillum lipoferum. Journal of Bacteriology 171, 3504-3510.

Eyers, M., VANDERLEYDEN, J. \& VAN GoOl, A. (1988). Attachment of Azospirillum to isolated plant cells. FEMS Microbiology Letters 49, 435-439.

FLETCHER, M. (1976). The effect of proteins on bacterial attachment to polystyrene. Journal of General Microbiology 94, 400-404.

FLETCHER, M. (1977). The effects of culture concentration and age, time, and temperature on bacterial attachment to polystyrene. Canadian Journal of Microbiology 23, 1-6.

FLETCHER, M. \& LOEB, G. I. (1979). Influence of substratum characteristics on the attachment of a marine pseudomonad to solid surfaces. Applied and Environmental Microbiology 37, 67-72.

GAFNI, R., OKON, Y., KAPULNIK, Y. \& FiSCHER, M. (1986). Adsorption of Azospirillum brasilense to corn roots. Soil Biology and Biochemistry 18, 69-75.

Harris, J. M., Lucas, J. A., Davey, M. R., Lethbridge, G. \& Powell, K. A. (1989). Establishment of Azospirillum inoculant in the rhizosphere of winter wheat. Soil Biology and Biochemistry 21, 59-64.

James, D. W., JR, Suslow, T. V. \& Steinback, K. E. (1985). Relationship between rapid, firm adhesion and long-term colonization of roots by bacteria. Applied and Environmental Microbiology 50, 392-397.

KiJNe, J. W., Smit, G., Diaz, C. L. \& LugtenberG, B. J. J. (1988). Lectin-enhanced accumulation of manganese-limited Rhizobium leguminosarum on pea root hair tips. Journal of Bacteriology 170, 2994-3000.

KLOTZ, S. A. (1990). Role of hydrophobic interactions in microbial adhesion to plastics used in medical devices. In Microbial Cell Surface Hydrophobicity, pp. 107-136. Edited by R. J. Doyle \& M. Rosenberg. Washington, DC: American Society for Microbiology.

LEVANONY, Y. \& BASHAN, Y. (1991). Active attachment of Azospirillum brasilense to root surface of non-cereal plants and to sand particles. Plant and Soil 137, 91-97.

LeVanony, H., Bashan, Y. \& Kahana, Z. E. (1987). Enzyme-linked immunosorbent assay for specific identification and enumeration of Azospirillum brasilense $\mathrm{Cd}$ in cereal roots. Applied and Environmental Microbiology 53, 358-364.

Levanony, H., Bashan, Y., Romano, B. \& Klein, E. (1989). Ultrastructural localization and identification of Azospirillum brasilense $\mathrm{Cd}$ on and within wheat root by immunogold labeling. Plant and Soil 117, 207-218.

MADI, L. \& HenIS, Y. (1989). Aggregation in Azospirillum brasilense 
$\mathrm{Cd}$ : conditions and factors involved in cell-to-cell adhesion. Plant and Soil 115, 89-98.

Marshall, K. C. (1986). Adsorption and adhesion processes in microbial growth at interfaces. Advances in Colloid Interface Science 25, 59-86.

Michiels, K. W., Croes, C. L. \& Vanderleyden, J. (1991). Two different modes of attachment of Azospirillum brasilense $\mathrm{Sp} 7$ to wheat roots. Journal of General Microbiology 137, 2241-2246.

Michiels, K. W., Verreth, C. \& Vanderleyden, J. (1990). Azospirillum lipoferum and Azospirillum brasilense surface polysaccharide mutants that are affected in flocculation. Journal of Applied Bacteriology 69, 705-711.

OKon, Y., Albrecht, S. L. \& BurRis, R. H. (1977). Methods for growing Spirillum lipoferum and for counting it in pure culture and in association with plants. Applied and Environmental Microbiology $33,85-88$.

SMIT, G. \& STACEY, G. (1990). Adhesion of bacteria to plant cells: role of specific interactions versus hydrophobicity. In Microbial Cell Surface Hydrophobicity, pp. 179-210. Edited by R. J. Doyle \& M. Rosenberg. Washington, DC: American Society for Microbiology. 